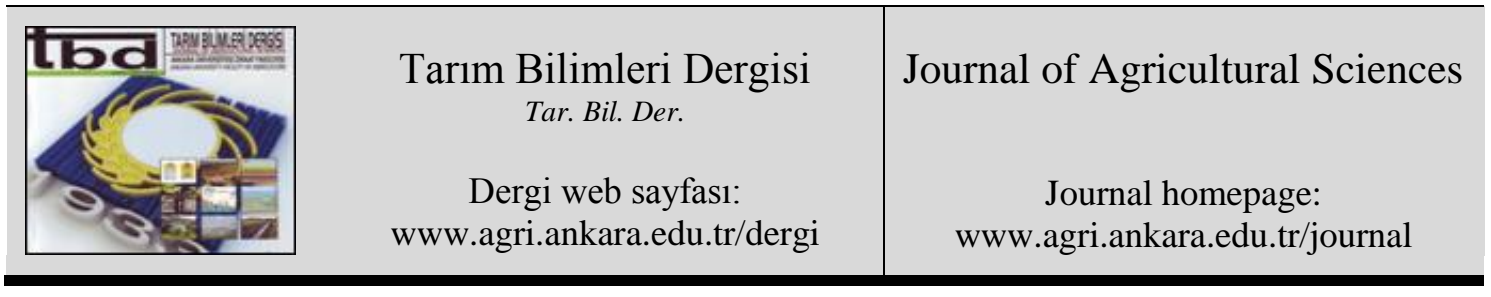

\title{
Intermittent Microwave Drying of Apple Slices: Drying Kinetics, Modeling, Rehydration Ratio and Effective Moisture Diffusivity
}

\author{
Nazmi İZLÍa ${ }^{a}$, Ahmet POLAT ${ }^{\mathrm{a}}$

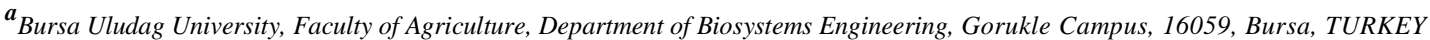

\section{ARTICLE INFO}

Research Article

Corresponding Author: Nazmi İZLİ, E-mail: nazmiizli@gmail.com, Tel: +90 (224) 2941604

Received: 27 September 2018, Received in Revised Form: 20 November 2018, Accepted: 22 November 2018

\section{AUTHORS ORCID ID}

(Nazmi İZLİ: 0000-0002-2084-4660), (Ahmet POLAT: 0000-0003-1673-7165)

\begin{abstract}
In this research, thin layer drying characteristics, rehydration ratio and effective moisture diffusivity of apple were investigated using microwave dryer which has intermittent and continuous modes. Drying time varied between 25 and 215 minutes and they declined with the rise in microwave power and reduction in pulsing ratio. In an attempt to pick the optimum thin layer models for the drying applications, 8 mathematical models suited to the experimental results. On the grounds of the statistical tests evaluation, Midilli et al model which represent drying characteristics are optimally
\end{abstract}

suited than other models. The highest rehydration ratio was recorded for the samples dried at 100W continuous mode and the lowest ratio at $300 \mathrm{~W}$ continuous application. Effective moisture diffusivity values were computed by the $2^{\text {nd }}$ law of Fick and changing between $3.04 \times 10^{-9}$ and $2.53 \times 10^{-8} \mathrm{~m}^{2} \mathrm{~s}^{-1}$. Consequently, the intermittent microwave method could be used as a favorable drying method for obtaining high-quality fruit slices or processing valuable material and continuous microwave drying can be taken as another drying approach for apple samples.

Keywords: Apple; Drying characteristics; Rehydration ratio; Effective moisture diffusivity

(C) Ankara Üniversitesi Ziraat Fakültesi

\section{Introduction}

Apple is a fruit that exists all year long, low-calorie and rich in various vitamins, minerals, dietary fibers, and it is a plentiful source of dietary polyphenols. For this reason, it is favorable for normal growth, development and consequentially for the whole well-being. It is noted that consuming apple helps human to refrain and protect from several diseases such as the risk of certain cancer types, ischemic heart diseases, thrombotic stroke, type 2 diabetes, and asthma (Saxena et al 2016). Apples are consumed as both fresh fruits and other processed products such as jams, juices, marmalades and other dehydrated products (An et al 2015). Food drying has been extensively used throughout the world history and it has provided elasticity in the utilization of foods in their offseason. Now, the industry on the dehydration of foods holds down a crucial position among other food industries across the globe. During drying, several modifications may occur at inner section of the foods, and these physicochemical and structural modifications have an impact on the attributes of the product: composition, color, and texture. However, those attributes connected with the transfer of heat and mass. In the literature, it is seen that transference of moisture, physical structures, and chemical configuration generally varies in foods (Cruz et al 2015). Microwave drying method is an 
alternative procedure so as to save time and energy. In this method, a microwave field induces volumetric heating of the wet solid, causing a water vapor pressure gradient between the surface and inner section of the material and accelerating the transfer of moisture (Junqueira et al 2017). However, the main disadvantage of using microwave method is the non-uniform distribution of moisture and temperature, that finding in cold and hot spots on the heated product. Intermittent application of microwave is one of the applicable remedies to curtail non-uniformity (Gunasekaran \& Yang 2007). In literature, different variety of apple have been dried with different drying methods such as hot air (Sturm et al 2014), explosion puffing (Yi et al 2016) and freeze drying (Djekic et al 2018) by many researchers. However, there are limited studies intermittent and continuous microwave on drying apple (Aghilinategh et al 2015). In addition, the intermittent microwave has successfully been applied on a limited number of agricultural products, for instance, pistachio nuts (Kermani et al 2017) and quince (Dehghannya et al 2018). The targets of this work were to (1) settle the effect of different intermittent microwave conditions on thin layer drying kinetics of apple samples, (2) pick the most favorable drying models and (3) evaluate the quality of dried apples by analyzing the effective moisture diffusivity and rehydration ratio parameters.

\section{Material and Methods}

\subsection{Drying equipment}

Fresh 'Granny Smith' variety of apple samples disposed of in the experiments were bought from a local market in Bursa province of Turkey and kept at $4 \pm 0.5{ }^{\circ} \mathrm{C}$ temperature until completion of the experiments. In advance of the drying processes, the apple samples were peeled and sliced into $5 \mathrm{~mm}$ thickness by using a dicer (Börner, Wingene, Belgium) and dried in this form. The initial moisture level of these samples was computed to be 4.76 ( $\mathrm{g}$ water $\mathrm{g}$ dry matter $^{-1}$ ) on a dry basis (d.b.) by use of forced air convection oven (ED115 Binder, Germany) drying at $105{ }^{\circ} \mathrm{C}$ for 24 hours period. The drying experiments were performed in a modified laboratory microwave oven. In this oven, microwave power between 80 and $900 \mathrm{~W}$ can be applied either in pulsed or continuous mode. Our experimental conditions were: three levels of microwave power (100, 200 and $300 \mathrm{~W})$, continuous and two pulsed operating modes. The microwave operating mode was assigned a pulsing ratio (PR), which is computed using Equation 1 where $t_{\text {on }}$ corresponds to magnetron power on-time and $t_{\text {off }}$ corresponds magnetron off-time (Gunasekaran \& Yang 2007).

$\mathrm{PR}=\frac{\left(t_{\text {on }}+t_{\text {off }}\right)}{\left(t_{\text {on }}\right)}$

For the continuous mode PR=1 $\left(t_{\text {on }}=60 \mathrm{~s}\right.$ and $\left.t_{\text {off }}=0 \mathrm{~s}\right)$ and for pulsed mode $\mathrm{PR}=2\left(t_{\text {on }}=30 \mathrm{~s}\right.$ and $\left.t_{\text {off }}=30 \mathrm{~s}\right)$ and $\mathrm{PR}=3\left(t_{\text {on }}=20 \mathrm{~s}\right.$ and $\left.t_{\text {off }}=40 \mathrm{~s}\right)$. The loss of moisture was recorded by taking the apple sample from the oven at 5-min intervals and weighing it on a digital balance (Shimadzu, Japan) that has a precision level of $0.01 \mathrm{~g}$; the sample was returned to the oven within $20 \mathrm{~s}$ for continued drying (Kayisoglu \& Ertekin 2011)

2.2. Mathematical modeling

The results data on moisture ratio $(M R)$ were fitted with 8 commonly used drying equations (Table 1$)$. The $M R$ and drying rate $(D R)$ are determined as follows (Kipcak 2017):

$$
\begin{aligned}
& M R=\frac{M_{t}-M_{e}}{M_{o}-M_{e}} \\
& D R=\frac{M_{t+d t}-M_{t}}{d t}
\end{aligned}
$$


In the foregoing formula $M_{o}$ corresponds the moisture content level at the beginning, $M_{t}$ corresponds the moisture content level at a given time, $M_{e}$ corresponds the equilibrium level of moisture content, $M_{t+d t}$ is the moisture content at $t+d t$ and $t$ is the drying time (min). After analyzing the formula, the values of $M_{e}$ are rather small concerning $M_{t}$ or $M_{o}$. Ultimately as proposed by some of the researchers, the moisture ratio formula was shortened in this way:

$$
M R=\frac{M_{t}}{M_{o}}
$$

Table 1- Thin layer drying models used for the apple drying kinetics

\begin{tabular}{rlll}
\hline No & Model name & Model & References \\
\hline 1 & Henderson and Pabis & $M R=a \exp (-k t)$ & Doymaz et al (2015) \\
2 & Newton & $M R=\exp (-k t)$ & Horuz et al (2018) \\
3 & Page & $M R=\exp \left(-k t^{n}\right)$ & Coradi et al (2017) \\
4 & Logarithmic & $M R=a \exp (-k t)+c$ & Kayran \& Doymaz (2017) \\
5 & Two-term model & $M R=a \exp \left(-k_{0} t\right)+b \exp \left(-k_{1} t\right)$ & Murthy \& Manohar (2014) \\
6 & Wang and Singh & $M R=1+a t+b t^{2}$ & Doymaz et al (2015) \\
7 & Diffusion Approach & $M R=a \exp (-k t)+(1-a) \exp (-k b t)$ & Murthy \& Manohar (2014) \\
8 & Midilli et al & $M R=a \exp \left(-k t^{n}\right)+b t$ & Kayran \& Doymaz (2017) \\
\hline
\end{tabular}

\subsection{Rehydration ratio measurement}

Prior to the execution of the analysis of the quality features, slices of the dried apple $(10.0 \pm 0.1 \mathrm{~g})$ were placed inside distilled water at $20^{\circ} \mathrm{C}$ for $14 \mathrm{~h}$, by being adhered to 1:50 solid to liquid ratio. (Vega-Gálvez et al 2009) The apple slices were then taken out, drained for $30 \mathrm{~s}$, and weighed out using an electronic digital balance (Shimadzu, Japan) having $\pm 0.001 \mathrm{~g}$ accuracy. For each application, this procedure was repeated in triplicate. Eventually, rehydration ratio $(R)$ was computed using Equation 5 as (Sunjka et al 2008) where, $M_{1}$ and $M_{2}$ are sample weights (g) before and after rehydration, respectively.

$R=\frac{M_{2}-M_{1}}{M_{1}}$

\subsection{Effective moisture diffusivity}

Drying of agricultural products in a falling rate period is embedded into a mass-diffusion equation in accordance with the second law of Fick on diffusion is presented in Equation (6) below:

$\frac{\partial M}{\partial t}=\nabla M\left[\mathrm{D}_{\mathrm{eff}}(\nabla \mathrm{M})\right]$

The Equation (6) that explains the $2^{\text {nd }}$ law of Fick on unsteady state diffusion can be utilized to figure out the moisture ratio calculated in Equation (7). The diffusion equation for infinite slab proposed by Kayran \& Doymaz (2017), and assumed uniform moisture distribution at the beginning, negligible shrinkage and external resistance, and constant diffusivity, is presented in the equation below: 
$M R=\frac{8}{\pi^{2}} \sum_{n=0}^{\infty} \frac{1}{(2 n+1)^{2}} \exp \left(-\frac{(2 n+1)^{2} \pi^{2} D_{e f f} t}{4 L^{2}}\right)$

Above; $D_{\text {eff }}$ corresponds to the effective moisture diffusivity $\left(\mathrm{m}^{2} \mathrm{~s}^{-1}\right), L$ corresponds to the half-thickness of samples (m), $t$ corresponds to the time (s), and $n$ corresponds to a positive integer. With regard to longer periods of drying, the foregoing equation can be shortened to an only first term of series, without having a significant impact on the accuracy of the assumption.

$M R=\frac{8}{\pi^{2}} \exp \left(-\frac{\pi^{2} D_{e f f} t}{4 L^{2}}\right)$

Typically, the effective moisture diffusivity $\left(D_{\text {eff }}\right)$ was also computed by means of the slope of Equation (8). Namely, a straight line with a slope of $K$ was derived when $\ln (M R)$ was plotted versus time:

$$
K=\frac{\pi^{2} D_{e f f}}{4 L^{2}}
$$

With the help of the slope value (Equation 9), the effective moisture diffusivity could be settled.

\subsection{Statistical analysis}

The study was realized by the aid of randomized plots factorial design. In the course of calculation of the inspected items, three replicates were utilized. While interpreting the outcomes, JMP (SAS Institute Inc., USA) and MATLAB (MathWorks Inc., MA) software technologies were employed. Significance levels of mean differences were tested and the least significant difference (LSD) test resulted in a 5\% significance level. It has been determined that the most convenient model that expresses the drying attributes of lime samples in a thin layer is the one that has lowest reduced chi-squared $\left(\chi^{2}\right)$ value, lowest root mean square error (RMSE ) value and the highest coefficient of determination $\left(R^{2}\right)$. The mentioned statistical values are described as below:

$$
\begin{aligned}
& R M S E=\sqrt{\frac{\sum_{i=1}^{N}\left(M R_{p r e, i}-M R_{\mathrm{exp}, i}\right)}{N}} \\
& \chi^{2}=\frac{\sum_{i=1}^{N}\left(M R_{\mathrm{exp}, i}-M R_{p r e, i}\right)^{2}}{N-z}
\end{aligned}
$$

Here; $M R_{\text {exp }, i}$ means the experimental $M R, M R{ }_{p r e, i}$, means the predicted $M R, N$ means the observation number and $z$ stands for the number of constants.

\section{Results and Discussion}

\subsection{Drying kinetics of apple}

The effects of continuous and intermittent microwave power on moisture content with drying period and drying rate versus drying period are presented in Figures 1 and 2, respectively. As it is presented in Figure 1 , the level of the microwave power had a remarkable impact on the moisture content of the apple samples, 
expectedly. The findings indicated that drying period got shorter substantially depending on increasing level of microwave power. Similar result has been found by Çelen et al (2011) with a 'Granny Smith' apple variety. For samples, the drying period required to attain the final moisture content $(0.1 \%$ d.b) was 80,150 and 215 minutes for $100 \mathrm{~W}-\mathrm{PR}=1, \mathrm{PR}=2$ and $\mathrm{PR}=3 ; 40,75$ and $125 \mathrm{~min}$ for $200 \mathrm{~W}-\mathrm{PR}=1, \mathrm{PR}=2$ and $\mathrm{PR}=$ 3 and 25,45 and $75 \mathrm{~min}$ for the $300 \mathrm{~W}-\mathrm{PR}=1, \mathrm{PR}=2$ and $\mathrm{PR}=3$, respectively. As the findings for the continuous mode, the sample at dried $300 \mathrm{~W}$ has a less drying period. At the greater microwave power levels, quicker transference of mass was realized because of the rise in heat production in the sample and hence the drying time became shorter (Kumar et al 2016). The findings indicate that all each microwave power levels of the $\mathrm{PR}=1$ application had the minimum drying period. Therefore, the total drying period is shorter in the continuous mode than in the intermittent mode (Gunasekaran \& Yang 2007). At the outset of both drying processes, the drying rates were greater. It could be explained by a falling in each working cycle $\left(t_{o} \square+t_{o f f}\right)$ of the microwave for the intermittent microwave drying application. Seeing that microwave power off-time yields a rest period for the redistribution of temperature and moisture inside the food and by the way, microwave power on-time allows the period for warming-up (Beaudry et al 2003). The drying rates of each sample dried at continuous mode was higher than intermittent mode at first stages because of the giving constant microwave energy. Since the amount of moisture that apple slices contain was greater at the first stage of the drying, based upon the greater diffusion of moisture, absorption of microwave power and rates of drying were found to be more. As the drying process goes on, moisture loss of the product culminated in a fall in the absorption of microwave power and rates of drying (Soysal et al 2009). Identical findings were gathered with apple (Aghilinategh et al 2015), rice (Xu et al 2017) and mussels (Kipcak 2017).

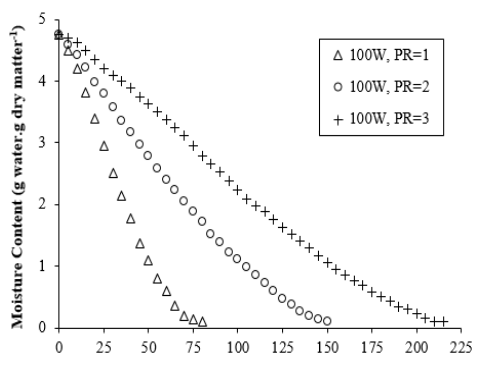

a)

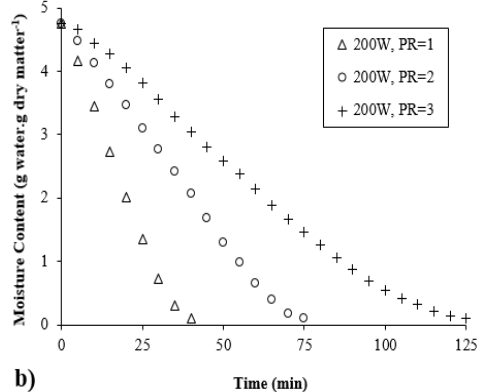

b)

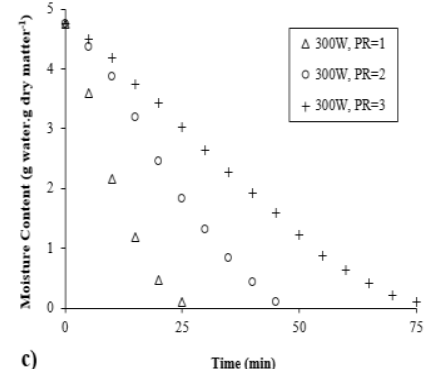

Figure 1- The moisture content of apple vs. time during pulsed microwave drying at different conditions
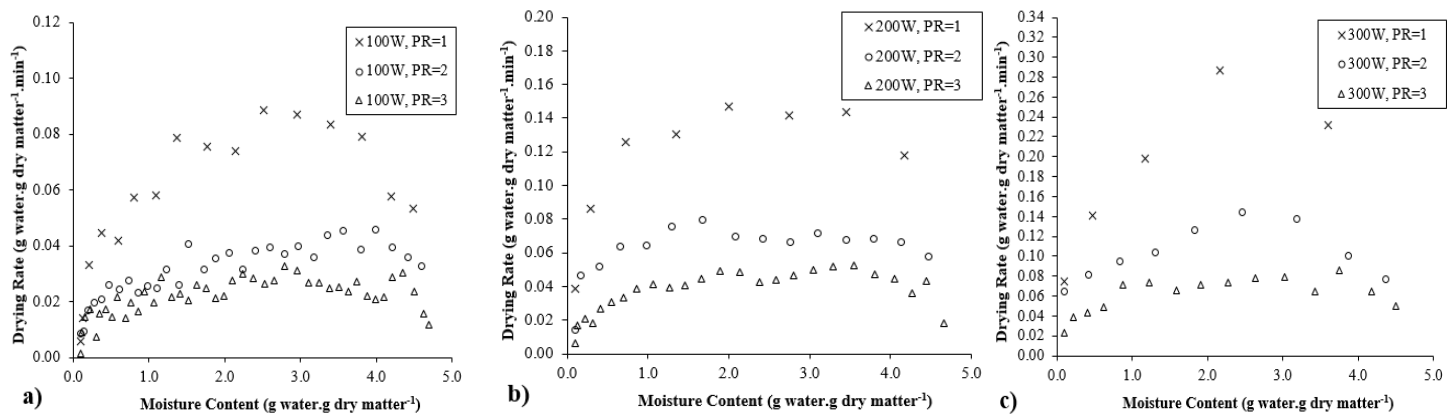

Figure 2- The drying rate vs. moisture content of apple at drying conditions

\subsection{Modeling of drying curves}

Table 2 shows the findings of the statistical analyses of the 8 distinct thin layer drying models, inclusive of drying model coefficients and the comparison criteria for assessing the quality of the model fit $\left(R^{2}, R M S E\right.$ and $\left.\chi^{2}\right) . R^{2}$ values were greater than 0.906, and RMSE and $\chi^{2}$ values were smaller than 0.102 and $94.386 \times 10^{-}$ ${ }^{4}$, respectively revealing good fit findings in all cases. Based on these findings, the Midilli et al model was the optimum of the evaluated models at explaining the variations in moisture ratios found in all tests. In addition, in all cases of the Midilli et al model $R^{2}$ values were more than 0.998; and the RMSE and $\chi^{2}$ values were less than 0.014 and $1.647 \times 10^{-4}$, in return. According to these computed findings, Midilli et al model 
can be considered as presenting the thin-layer drying behavior of the apple samples. The difference between the predicted and experimental moisture ratio using the most relevant models with drying period at picked temperatures and microwave power levels for dried apple is presented in Figure 3. Obviously, the findings obtained from the Midilli et al model are quite close to the experimental values. In addition, the Midilli et al model could adequately describe the drying curves of apple under the picked experimental conditions. The findings of this study are in agreement with former findings proclaimed in the drying of pulped coffee (Coradi et al 2017), guava pulp (Maciel et al 2017), and apricot halves (Kayran \& Doymaz 2017) for Midilli et al model.

Table 2- Forecasted data of statistical analyses obtained from thin layer drying models

\begin{tabular}{|c|c|c|c|c|}
\hline \multirow{2}{*}{ No } & \multicolumn{4}{|c|}{$100 W, P R=1$} \\
\hline & Model coefficients & $R^{2}$ & RMSE & $\chi^{2}\left(10^{-4}\right)$ \\
\hline 1 & $\mathrm{a}=1.126 ; \mathrm{k}=0.02965$ & 0.9498 & 0.0768 & 48.7908 \\
\hline 2 & $\mathrm{k}=0.02635$ & 0.9331 & 0.0886 & 79.6781 \\
\hline 3 & $\mathrm{k}=0.002217 ; \mathrm{n}=1.669$ & 0.9975 & 0.0170 & 2.6731 \\
\hline 4 & $a=1.75 ; k=0.01212 ; c=-0.6973$ & 0.9914 & 0.0318 & 6.6619 \\
\hline 5 & $\mathrm{a}=43.38 ; \mathrm{k}_{0}=0.05617 ; \mathrm{b}=-42.37 ; \mathrm{k}_{1}=0.05754$ & 0.9904 & 0.0336 & 11.0080 \\
\hline 6 & $a=-0.01797 ; b=0.0000635$ & 0.9902 & 0.0340 & 11.5937 \\
\hline 7 & $\mathrm{a}=1.239 ; \mathrm{k}=0.02604 ; \mathrm{b}=0.9515$ & 0.9237 & 0.0947 & 84.8834 \\
\hline 8 & $\mathrm{a}=0.9867 ; \mathrm{k}=0.002567 ; \mathrm{n}=1.597 ; \mathrm{b}=-0.00069$ & 0.9994 & 0.0071 & 1.0405 \\
\hline \multirow{2}{*}{ No } & \multicolumn{4}{|c|}{$100 W, P R=2$} \\
\hline & Model coefficients & $R^{2}$ & RMSE & $\chi^{2}\left(10^{-4}\right)$ \\
\hline 1 & $\mathrm{a}=1.108 ; \mathrm{k}=0.01498$ & 0.9651 & 0.0583 & 29.4053 \\
\hline 2 & $\mathrm{k}=0.01344$ & 0.9506 & 0.0693 & 48.2401 \\
\hline 3 & $\mathrm{k}=0.001684 ; \mathrm{n}=1.478$ & 0.9946 & 0.0229 & 5.5703 \\
\hline 4 & $\mathrm{a}=1.738 ; \mathrm{k}=0.006021 ; \mathrm{c}=-0.7104$ & 0.9986 & 0.0115 & 0.8235 \\
\hline 5 & $a=16.34 ; \mathrm{k}_{0}=0.02637 ; \mathrm{b}=-15.32 ; \mathrm{k}_{1}=0.02787$ & 0.9907 & 0.0301 & 9.4359 \\
\hline 6 & $a=-0.009356 ; b=0.0000177$ & 0.9984 & 0.0124 & 1.3022 \\
\hline 7 & $\mathrm{a}=-0.3939 ; \mathrm{k}=0.01454 ; \mathrm{b}=0.9452$ & 0.9473 & 0.0716 & 49.7150 \\
\hline 8 & $a=0.9867 ; k=0.002566 ; n=1.266 ; b=0.00069$ & 0.9997 & 0.0052 & 0.2621 \\
\hline \multirow{2}{*}{ No } & \multicolumn{4}{|c|}{$100 W, P R=3$} \\
\hline & Model coefficients & $\mathrm{R}^{2}$ & RMSE & $\chi^{2}\left(10^{-4}\right)$ \\
\hline 1 & $\mathrm{a}=1.142 ; \mathrm{k}=0.009964$ & 0.9495 & 0.0714 & 42.6928 \\
\hline 2 & $\mathrm{k}=0.008636$ & 0.9243 & 0.0874 & 75.6288 \\
\hline 3 & $\mathrm{k}=0.000368 ; \mathrm{n}=1.665$ & 0.9947 & 0.0231 & 5.1703 \\
\hline 4 & $\mathrm{a}=2.518 ; \mathrm{k}=0.002557 ; \mathrm{c}=-1.474$ & 0.9969 & 0.0176 & 2.1284 \\
\hline 5 & $\mathrm{a}=27.07 ; \mathrm{k}_{0}=0.01854 ; \mathrm{b}=-26.05 ; \mathrm{k}_{1}=0.01925$ & 0.9864 & 0.0370 & 13.1762 \\
\hline 6 & $a=-0.005568 ; b=0.00000363$ & 0.9950 & 0.0225 & 4.3567 \\
\hline 7 & $\mathrm{a}=0.0000392 ; \mathrm{k}=0.01439 ; \mathrm{b}=0.5998$ & 0.9206 & 0.0896 & 77.4281 \\
\hline 8 & $a=0.9909 ; k=0.0006739 ; n=1.477 ; b=-0.00069$ & 0.9995 & 0.0069 & 0.3965 \\
\hline \multirow{2}{*}{ No } & \multicolumn{4}{|c|}{$200 W, P R=1$} \\
\hline & Model coefficients & $R^{2}$ & RMSE & $\chi^{2}\left(10^{-4}\right)$ \\
\hline 1 & $\mathrm{a}=1.092 ; \mathrm{k}=0.05347$ & 0.9387 & 0.0890 & 65.1837 \\
\hline 2 & $\mathrm{k}=0.04898$ & 0.9336 & 0.0927 & 83.5024 \\
\hline 3 & $\mathrm{k}=0.006074 ; \mathrm{n}=1.68$ & 0.9941 & 0.0277 & 7.6681 \\
\hline 4 & $a=2.24 ; \mathrm{k}=0.01576 ; \mathrm{c}=-1.212$ & 0.9928 & 0.0305 & 5.2148 \\
\hline 5 & $\mathrm{a}=56.74 ; \mathrm{k}_{0}=0.09428 ; \mathrm{b}=-55.72 ; \mathrm{k}_{1}=0.09573$ & 0.9733 & 0.0588 & 32.3902 \\
\hline 6 & $a=-0.03218 ; b=0.0001681$ & 0.9932 & 0.0297 & 6.3986 \\
\hline 7 & $a=-0.9022 ; k=0.05104 ; b=0.9784$ & 0.9115 & 0.1001 & 95.2979 \\
\hline 8 & $\mathrm{a}=0.9929 ; \mathrm{k}=0.008585 ; \mathrm{n}=1.492 ; \mathrm{b}=-0.00292$ & 0.9981 & 0.0156 & 2.2205 \\
\hline \multirow{2}{*}{ No } & \multicolumn{4}{|c|}{$200 W, P R=2$} \\
\hline & Model coefficients & $R^{2}$ & RMSE & $\chi^{2}\left(10^{-4}\right)$ \\
\hline 1 & $\mathrm{a}=1.114 ; \mathrm{k}=0.02691$ & 0.9338 & 0.0855 & 63.0934 \\
\hline 2 & $\mathrm{k}=0.02396$ & 0.9189 & 0.0946 & 88.3009 \\
\hline 3 & $\mathrm{k}=0.001702 ; \mathrm{n}=1.709$ & 0.9895 & 0.0340 & 11.8914 \\
\hline 4 & $a=4.225 ; \mathrm{k}=0.00379 ; \mathrm{c}=-3.202$ & 0.9964 & 0.0199 & 2.2661 \\
\hline 5 & $\mathrm{a}=41.86 ; \mathrm{k}_{0}=0.05235 ; \mathrm{b}=-40.82 ; \mathrm{k}_{1}=0.05364$ & 0.9733 & 0.0543 & 28.6440 \\
\hline 6 & $a=-0.01482 ; b=0.000015$ & 0.9960 & 0.0211 & 2.8826 \\
\hline 7 & $a=-0.5643 ; k=0.02561 ; b=0.9582$ & 0.9067 & 0.1015 & 94.3856 \\
\hline 8 & $\mathrm{a}=0.9875 ; \mathrm{k}=0.002866 ; \mathrm{n}=1.449 ; \mathrm{b}=-0.00301$ & 0.9983 & 0.0136 & 1.6468 \\
\hline
\end{tabular}

Tarım Bilimleri Dergisi - Journal of Agricultural Sciences 26 (2020) 32-41 
Table 2 (Continue)- Forecasted data of statistical analyses obtained from thin layer drying models

\begin{tabular}{|c|c|c|c|c|}
\hline \multirow{2}{*}{ No } & \multicolumn{4}{|c|}{$200 W, P R=3$} \\
\hline & Model coefficients & $R^{2}$ & RMSE & $\chi^{2}\left(10^{-4}\right)$ \\
\hline 1 & $\mathrm{a}=1.14 ; \mathrm{k}=0.01756$ & 0.9485 & 0.0747 & 46.2486 \\
\hline 2 & $\mathrm{k}=0.0153$ & 0.9251 & 0.0900 & 81.4717 \\
\hline 3 & $\mathrm{k}=0.0008704 ; \mathrm{n}=1.683$ & 0.9959 & 0.0211 & 4.4787 \\
\hline 4 & $\mathrm{a}=2.234 ; \mathrm{k}=0.005249 ; \mathrm{c}=-1.184$ & 0.9953 & 0.0226 & 3.1747 \\
\hline 5 & $\mathrm{a}=26 ; \mathrm{k}_{0}=0.03326 ; \mathrm{b}=-24.99 ; \mathrm{k}_{1}=0.03465$ & 0.9882 & 0.0357 & 12.8191 \\
\hline 6 & $a=-0.00997 ; b=0.000014$ & 0.9928 & 0.0279 & 6.7776 \\
\hline 7 & $a=1.968 ; k=0.01472 ; b=0.961$ & 0.9189 & 0.0936 & 84.4770 \\
\hline 8 & $\mathrm{a}=0.9938 ; \mathrm{k}=0.001395 ; \mathrm{n}=1.519 ; \mathrm{b}=-0.00090$ & 0.9994 & 0.0083 & 0.5989 \\
\hline \multirow{2}{*}{ No } & \multicolumn{4}{|c|}{$300 W, P R=1$} \\
\hline & Model coefficients & $R^{2}$ & RMSE & $\chi^{2}\left(10^{-4}\right)$ \\
\hline 1 & $\mathrm{a}=1.055 ; \mathrm{k}=0.09247$ & 0.9571 & 0.0800 & 53.4380 \\
\hline 2 & $\mathrm{k}=0.08809$ & 0.9607 & 0.0765 & 55.6568 \\
\hline 3 & $\mathrm{k}=0.02202 ; \mathrm{n}=1.547$ & 0.9987 & 0.0137 & 1.8168 \\
\hline 4 & $a=1.497 ; k=0.04614 ; c=-0.4759$ & 0.9906 & 0.0375 & 11.7476 \\
\hline 5 & $\mathrm{a}=8.206 ; \mathrm{k}_{0}=0.1767 ; \mathrm{b}=-7.208 ; \mathrm{k}_{1}=0.2022$ & 0.9939 & 0.0302 & 8.3524 \\
\hline 6 & $a=-0.06244 ; b=0.0009068$ & 0.9946 & 0.0283 & 7.5788 \\
\hline 7 & $a=1.063 ; k=0.08767 ; b=0.925$ & 0.9346 & 0.0987 & 69.5035 \\
\hline 8 & $a=1.001 ; k=0.02614 ; n=1.444 ; b=-0.00182$ & 0.9997 & 0.0064 & 0.6431 \\
\hline \multirow{2}{*}{ No } & \multicolumn{4}{|c|}{$300 W, P R=2$} \\
\hline & Model coefficients & $R^{2}$ & $R M S E$ & $\chi^{2}\left(10^{-4}\right)$ \\
\hline 1 & $\mathrm{a}=1.111 ; \mathrm{k}=0.0441$ & 0.9328 & 0.0912 & 68.1232 \\
\hline 2 & $\mathrm{k}=0.03947$ & 0.9211 & 0.0294 & 88.0011 \\
\hline 3 & $\mathrm{k}=0.00339 ; \mathrm{n}=1.761$ & 0.9965 & 0.0208 & 4.0195 \\
\hline 4 & $\mathrm{a}=3.298 ; \mathrm{k}=0.008451 ; \mathrm{c}=-2.26$ & 0.9930 & 0.0294 & 6.6326 \\
\hline 5 & $\mathrm{a}=21.46 ; \mathrm{k}_{0}=0.08827 ; \mathrm{b}=-20.45 ; \mathrm{k}_{1}=0.09305$ & 0.9851 & 0.0429 & 18.1082 \\
\hline 6 & $\mathrm{a}=-0.0246 ; \mathrm{b}=0.000048$ & 0.9916 & 0.0322 & 10.0784 \\
\hline 7 & $a=25.28 ; k=0.02298 ; b=0.9754$ & 0.9278 & 0.0945 & 78.2707 \\
\hline 8 & $a=0.9987 ; k=0.004916 ; n=1.576 ; b=-0.00254$ & 0.9996 & 0.0074 & 0.4178 \\
\hline \multirow{2}{*}{ No } & \multicolumn{4}{|c|}{$300 W, P R=3$} \\
\hline & Model coefficients & $R^{2}$ & $R M S E$ & $\chi^{2}\left(10^{-4}\right)$ \\
\hline 1 & $\mathrm{a}=1.119 ; \mathrm{k}=0.02798$ & 0.9451 & 0.0782 & 51.5717 \\
\hline 2 & $\mathrm{k}=0.02484$ & 0.9285 & 0.0892 & 79.3566 \\
\hline 3 & $\mathrm{k}=0.0021 ; \mathrm{n}=1.667$ & 0.9946 & 0.0245 & 6.7456 \\
\hline 4 & $\mathrm{a}=2.514 ; \mathrm{k}=0.007219 ; \mathrm{c}=-1.478$ & 0.9959 & 0.0213 & 2.5684 \\
\hline 5 & $\mathrm{a}=35.16 ; \mathrm{k}_{0}=0.05173 ; \mathrm{b}=-34.12 ; \mathrm{k}_{1}=0.05314$ & 0.9821 & 0.0446 & 19.5241 \\
\hline 6 & $\mathrm{a}=-0.01608 ; \mathrm{b}=0.000033$ & 0.9946 & 0.0245 & 4.5823 \\
\hline 7 & $a=5.073 ; k=0.01659 ; b=0.8993$ & 0.9369 & 0.0839 & 65.0382 \\
\hline 8 & $\mathrm{a}=0.9945 ; \mathrm{k}=0.003396 ; \mathrm{n}=1.462 ; \mathrm{b}=-0.00192$ & 0.9993 & 0.0091 & 0.8938 \\
\hline
\end{tabular}
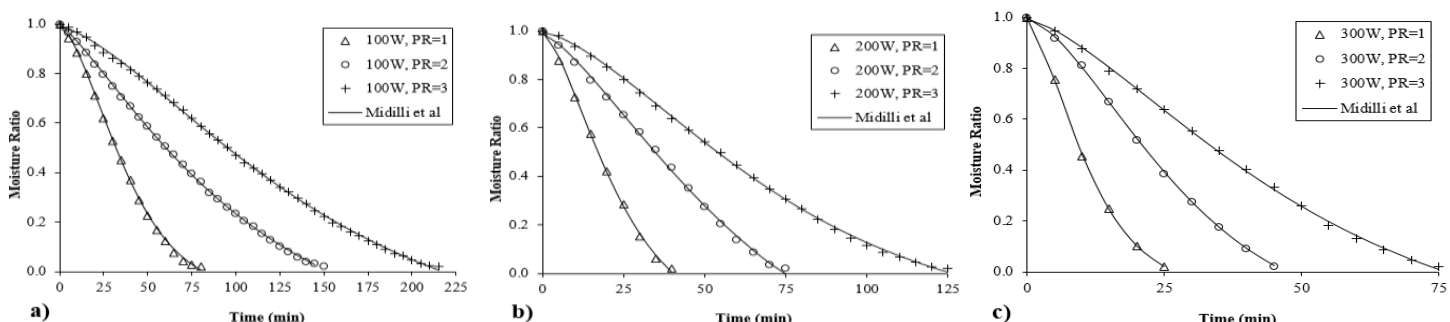

Figure 3- A comparison of the appropriate model to experimental moisture ratios at specific drying times

\subsection{Rehydration ratio}

Rehydration is a sophisticated operation and it points out the physical and chemical modifications triggered by drying applications. It has been detected from Figure 4 that the highest rehydration ratio has computed at drying $100 \mathrm{~W}-\mathrm{PR}=1$ microwave application and lowest value has been seen drying at $300 \mathrm{~W}-\mathrm{PR}=1$ mode. 
The finding pointed out that the increase in microwave power supported the decrease in rehydration capacity. To make it clear, during drying at high microwave powers, permanent cellular rupture and dislocation happens, introduces tissue integrity loss and produces a dense structure of collapsed, substantially shrunken capillaries with reduced hydrophilic attributes. The reduced hydrophilic attributes came up with lower rehydration capacity values, prevented imbibition of water, and left unfilled pores behind (Horuz et al 2018). The findings showed that the rehydration ratio of $P R=3$ has the highest level to $\mathrm{PR}=1$ and $\mathrm{PR}=2$ for $200 \mathrm{~W}$ and $300 \mathrm{~W}$ microwave power levels. A similar observation has been seen by Aghilinategh et al (2015) with apple.

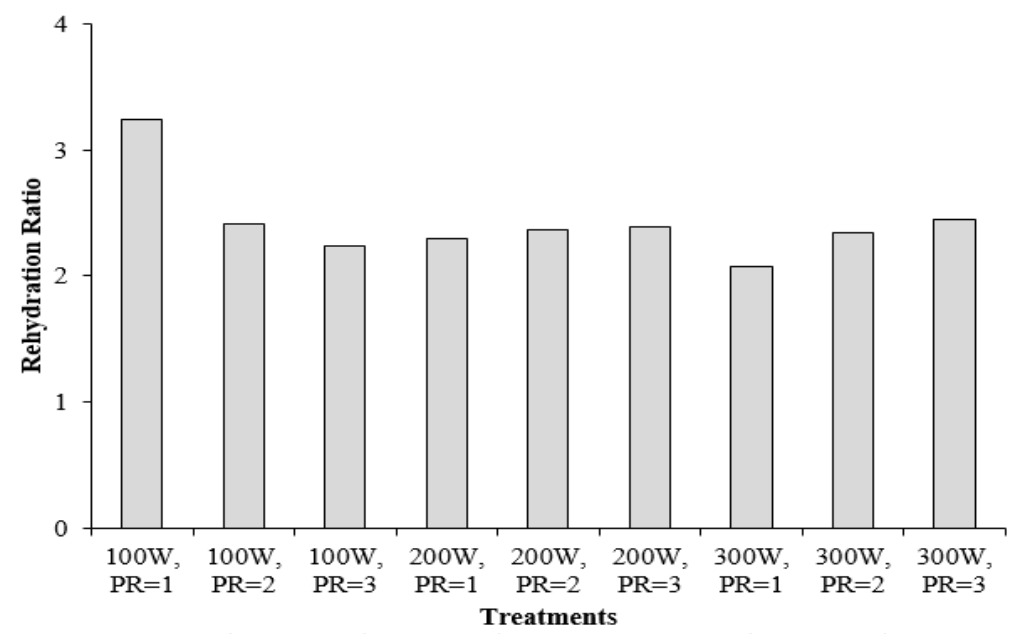

Figure 4- The rehydration ratio results of apple under drying conditions

\subsection{Effective moisture diffusivity}

The effective diffusivity values of $100 \mathrm{~W}-\mathrm{PR}=1, \mathrm{PR}=2$ and $\mathrm{PR}=3 ; 200 \mathrm{~W}-\mathrm{PR}=1, \mathrm{PR}=2$ and $\mathrm{PR}=3$ and $300 \mathrm{~W}-\mathrm{PR}=1, \mathrm{PR}=2$ and $\mathrm{PR}=3$, drying conditions ranged from $8.11 \times 10^{-9}, 4.05 \times 10^{-9}, 3.04 \times 10^{-9} ; 1.52 \times 10^{-}$ ${ }^{8}, 8.11 \times 10^{-9}, 5.07 \times 10^{-9}$ and $2.53 \times 10^{-8}, 1.22 \times 10^{-8}$ and $8.11 \times 10^{-9} \mathrm{~m}^{2} \mathrm{~s}^{-1}$, respectively. The values of effective moisture diffusivities in continuous and intermittent microwave dried apple (Red delicious variety) has been given by Aghilinategh et al (2015). There have been differences between with our presented values. This differences may occur using different varieties of apples. It is easy to observe that $D_{\text {eff }}$ values upsurge substantially with the rise in microwave power. The reason for this may be the rise in microwave power led to a sudden rise in the sample temperature that consecutively boosted the vapor pressure. The effective moisture diffusivity value has been found higher at drying applications run at continuous microwave drying mode concerning the ones run at the intermittent mode. Because the continuous mode of microwave evokes the rise in temperature and correspondingly the water vapor pressure more than that of the intermittent mode, that assists the moisture diffusion on the product surface. As the PR number increases, effective moisture diffusivity decreases. This may be because of sample cooling as a result of power-off-times at high pulsing ratios. Similar observations were recorded by Sharifian et al (2015) with fig fruit. Doymaz et al (2015) reported that moisture diffusivity of dried bean ranged from $1.387 \times 10^{-8}$ and $3.724 \times 10^{-8} \mathrm{~m}^{2} \mathrm{~s}^{-1}$ at $180-800 \mathrm{~W}$ microwave power. Puangsuwan et al (2015) also found that the $D_{\text {eff }}$ of palm fruit increases with microwave power. The values of moisture diffusivity values found in our research almost in line with the values reported in the literature, whereas there exist some variations. These variations may arise from the geometric shape and type, moisture content at the beginning and in the end and also chemical and physical attributes of products, dryer type and pre-applications (Horuz et al 2018).

\section{Conclusions}

In this research, the effect of different continuous and intermittent microwave drying applications on the drying kinetics, rehydration ratio and effective moisture diffusivity attributes of apple samples were explored. The findings verified that continuous microwave drying provides more positive effect drying period and drying rate than the intermittent mode. Midilli et al is the model that optimally represents the 
drying curves of apple slices at all microwave power levels and pulsing modes. Highest values of rehydration and are obtained for apple dried at $100 \mathrm{~W}-\mathrm{PR}=1$ application. Effective moisture diffusivity of dried apple, ranged from $3.04 \times 10^{-9}$ and $2.53 \times 10^{-8} \mathrm{~m}^{2} \mathrm{~s}^{-1}$ at microwave power of $100 \mathrm{~W}-\mathrm{PR}=3$ and $300 \mathrm{~W}-$ $\mathrm{PR}=1$ mode, respectively. The findings of the current study pointed out that intermittent and continuous modes of microwave drying are an appropriate alternative for drying apple.

\begin{tabular}{|ll|}
\hline \multicolumn{2}{|l|}{ Abbreviations and Symbols } \\
\hline$M_{0}$ & Initial moisture content \\
$M_{t}$ & The moisture content at a particular time \\
$M_{e}$ & Equilibrium moisture content \\
$M R_{\text {exp }, i}$ & Experimental moisture ratio at the test number i, \\
$M R_{p r e, i}$ & Predicted moisture ratio at the test number i, \\
$N$ & Observation number \\
$z$ & Total count of constant \\
$R M S E$ & Root mean square error \\
$R^{2}$ & Coefficient of determination \\
$\chi^{2}$ & Reduced chi-square \\
$a, b, c, n, k_{o}, k_{l}$ & Model constants \\
$D_{e f f}$ & Effective moisture diffusivity \\
\hline
\end{tabular}

\section{References}

Aghilinategh N, Rafiee S, Gholikhani A, Hosseinpur S, Omid M, Mohtasebi S S \& Maleki N (2015). A comparative study of dried apple using hot air, intermittent and continuous microwave: evaluation of kinetic parameters and physicochemical quality attributes. Food Science \& Nutrition 3(6): 519-526

An F, Qiu D, Song H, Wu X, Tong J \& Guo R (2015). Effects of instant pressure drop puffing with super-heated vapor on the physical properties of Granny Smith apple chips. Journal of Food Process Engineering 38(2): 174-182

Beaudry C, Raghavan G S V \& Rennie T J (2003). Microwave finish drying of osmotically dehydrated cranberries. Drying Technology 21(9): 1797-1810

Çelen S, Kahveci K \& Akyol U (2011). Single layer drying behavior of apple slices in a microwave dryer. In Defect and Diffusion Forum 312: 842-847

Coradi P C, Borém F M \& Reinato C H (2017). Mathematical modeling of drying the pulped coffee (Coffea arabica L.) at different air conditions. Revista Brasileira de Tecnologia Agroindustrial 11(2): 2397-2419

Cruz A C, Guiné R P \& Gonçalves J C (2015). Drying kinetics and product quality for convective drying of apples (cvs. Golden Delicious and Granny Smith). International Journal of Fruit Science 15(1): 54-78

Dehghannya J, Hosseinlar S H \& Heshmati M K (2018). Multi-stage continuous and intermittent microwave drying of quince fruit coupled with osmotic dehydration and low temperature hot air drying. Innovative Food Science \& Emerging Technologies 45: 132-151

Djekic I, Tomic N, Bourdoux S, Spilimbergo S, Smigic N, Udovicki B, Hofland G, Devlieghere F, Rajkovic A \& Rajkovic A (2018). Comparison of three types of drying (supercritical CO2, air and freeze) on the quality of dried apple-Quality index approach. LWT 94: 64-72

Doymaz I, Kipcak A S \& Piskin S (2015). Microwave drying of green bean slices: Drying kinetics and physical quality. Czech Journal of Food Science 33(4): 367-376

Gunasekaran S \& Yang H W (2007). Optimization of pulsed microwave heating. Journal of Food Engineering 78(4): $1457-1462$

Horuz E, Bozkurt H, Karataş H \& Maskan M (2018). Simultaneous application of microwave energy and hot air to whole drying process of apple slices: Drying kinetics, modeling, temperature profile and energy aspect. Heat and Mass Transfer 54(2): 425-436 
Junqueira J R D J, Corrêa J L G \& Ernesto D B (2017). Microwave, convective, and intermittent microwave-convective drying of pulsed vacuum osmodehydrated pumpkin slices. Journal of Food Processing and Preservation 41(6): 1-

Kayisoglu S \& Ertekin C (2011). Vacuum drying kinetics of Barbunya bean (Phaseolus vulgaris L. elipticus Mart.). The Philippine Agricultural Scientist 94(3): 285-291

Kayran S \& Doymaz İ (2017). Infrared drying and effective moisture diffusivity of apricot halves: Influence of pretreatment and infrared power. Journal of Food Processing and Preservation 41(2): 1-8

Kermani A M, Khashehchi M, Kouravand S \& Sadeghi A (2017). Effects of intermittent microwave drying on quality characteristics of pistachio nuts. Drying Technology 35(9): 1108-1116

Kipcak A S (2017). Microwave drying kinetics of mussels (Mytilus edulis). Research on Chemical Intermediates 43(3): $1429-1445$

Kumar V, Sharma H K \& Singh K (2016). Mathematical modeling of thin layer microwave drying of taro slices. Journal of the Institution of Engineers (India): Series A 97(1): 53-61

Maciel R M, Afonso M R, Costa J, Severo L S \& Lima N D D (2017). Mathematical modeling of the foam-mat drying curves of guava pulp. Revista Brasileira de Engenharia Agricola e Ambiental 21(10): 721-725

Murthy T P K \& Manohar B (2014). Hot air drying characteristics of mango ginger: Prediction of drying kinetics by mathematical modeling and artificial neural network. Journal of Food Science and Technology 51(12): 3712-3721

Puangsuwan K, Chongcheawchamnan M \& Tongura C (2015). Effective moisture diffusivity, activation energy and dielectric model for palm fruit using a microwave heating. Journal of Microwave Power and Electromagnetic Energy 49(2): 100-111

Saxena S, Verma J \& Gautam S (2016). Potential prophylactic properties of apple and characterization of potent bioactive from cv. "Granny Smith" displaying strong antimutagenicity in models including human lymphoblast TK6+/- cell line. Journal of Food Science 81(2): 508-518

Sharifian F, Nikbakht A M, Arefi A \& Modarres Motlagh A (2015). Experimental assessment of energy and mass transfer in microwave drying of fig fruit. Journal of Agricultural Science and Technology 17: 1695-1705

Soysal Y, Ayhan Z, Eştürk O \& Arıkan M F (2009). Intermittent microwave-convective drying of red pepper: Drying kinetics, physical (colour and texture) and sensory quality. Biosystems Engineering 103(4): 455-463

Sturm B, Vega A M N \& Hofacker W C (2014). Influence of process control strategies on drying kinetics, colour and shrinkage of air dried apples. Applied Thermal Engineering 62(2): 455-460

Sunjka P S, Orsat V \& Raghavan G S V (2008). Microwave/vacuum drying of cranberries (Vacccinium macrocarpon). American Journal of Food Technology 3(2): 100-108

Vega-Gálvez A, Di Scala K, Rodríguez K, Lemus-Mondaca R, Miranda M, López J \& Perez-Won M (2009). Effect of air-drying temperature on physico-chemical properties, antioxidant capacity, colour and total phenolic content of red pepper (Capsicum annuum, L. var. Hungarian). Food Chemistry 117(4): 647-653

Xu F, Chen Z, Huang M, Li C \& Zhou W (2017). Effect of intermittent microwave drying on biophysical characteristics of rice. Journal of Food Process Engineering 40(6): e12590. https://doi.org/10.1111/jfpe.12590

Yi J Y, Zhou L Y, Bi J F, Wang P, Liu X \& Wu X Y (2016). Influence of number of puffing times on physicochemical, color, texture, and microstructure of explosion puffing dried apple chips. Drying Technology 34(7): 773-782 